\title{
4 An Analysis of Part 5
}

In the Apology Gerasimus uses two levels of debate in the apologetical writings. The first level is the scholarly polemic that took place between Muslim and Christian intellectuals. It intends to lay out the issues in complex theological and philosophical categories. The second level is a popular polemic that extended to a wider range of participants, and was aimed at expressing teachings in a more simplistic form. ${ }^{63}$ This is indicative of the extent to which discussion of religion had spread; it no longer took place just among scholars, but common folk were also being urged to convert to Islam and therefore pressed into defending their beliefs.

Gerasimus uses the structure of formal debates. First, he describes the questioner's proof; second, he lays out the evidence; and third, he advocates the general validity of the proof. It is in this third step that he lays out his most important arguments. ${ }^{64}$

Unlike in Parts 1 to 3 of the Apology, Gerasimus avoids the use of analogy because he is aware that many Muslim theologians and jurists did not accept analogy or consensus as legitimate evidence. The respondent is therefore, required to base his argument on a foundation that both he and his opponent would find acceptable. Many, especially the Mu'tazila, found a solution in rationalism. Christians were quick to adopt this approach and respondents used a combination of reason and commonly accepted scriptural arguments to make their points. ${ }^{65}$

Gerasimus presents an objection by laying out a series of questions in such a way that as many objections as possible can be addressed. In nearly every Objection, he assumes that his Christian reader will participate in the position of the respondent and almost never the questioner. This can serve as a tool for his Christian readers to gain the upper hand in any potential debate and demonstrate the validity of the Christian view.

As a form of apologetic writing, such a presentation leads the reader to see the strength of Christian teaching in the face of difficult plausible questions. It also assists Christian intellectuals in adopting the developing debate structure and using it to their own advantage when they are called upon to defend their faith.

63 Cf. Graft 1926, 827; Griffith 2008, 75-105.

64 Cf. Keating 2006, 29-30.

65 Ibid. 30. 


\subsection{1st Objection: Christianity Is Not the True Religion}

\subsubsection{Summary of the Objection}

- Although you claim that God's name and power is honored throughout the world, there are more non-believers than believers in Him (vv. 2-5).

- Since God overlooked all the nations except Israel for thousands of years, other nations relied on religions that are equally plausible (vv. 6-9).

- With the ruin of your temples and the fall of your priesthood, with the defeat of your armies and loss of your worldwide influence, you now pay taxes to Muslims. Since your miracle working powers are gone, there is nothing to save you from the oppression of your enemies. Therefore, Christianity is not the true religion (vv. 10-17).

\subsubsection{Context of the Objection}

This objection originated in the context of growing numbers of Christians converting to Islam. It is not the purpose of this study to examine such social and religious phenomenon. Therefore, I will provide only a brief description of the context in which this objection developed. According to Richard Bulliet (1979, 81-82), the Abbasid period (A.D.750-1258) saw an unprecedented number of Christians accepting Islam. Based on the estimate of the Umayyad governor 'Ubayd Allāh Bin Ziyād, as of the year A.D. 675, only about three percent of the population in Iraq had converted to Islam. However, beginning with the reign of Caliph Harūn al-Rašìd (A.D. 786-809), the rate of conversions increased dramatically. By the mid-ninth century, the Muslim population of Iraq is thought to have reached nearly forty percent. ${ }^{66}$ This is also true for the other countries in the region. Such a social and religious phenomenon alarmed Christians. Christian apologetics at this time not only defended Christian beliefs but also endeavored to stem the tide of conversions away from the well established Christian church. Christian clergy and scholars were prompted to make their case in favor of Christianity in such a way as to defend its intelligibility and legitimacy in the face of Muslim criticism, as well as to calm fears and encourage confidence within the Christian population. ${ }^{67}$

In this context, the Qur'anic dialogue began with Jews and Christians about the true religion. According to the Qur'an, the true religion had never changed:

66 Cf. Levtzion 1990, 289-311; Reinink 1993, 165-187.

67 Keating 2006, 12. 
"Do you claim that Abraham and Ishmael and Isaac and Jacob and their descendants were Jews or Christian?" say: "Do you know more than God, Who is more unjust than he who conceals a testimony given to him by God? For God is not ignorant of what you do." 68

The Qur'an teaches that God's verbal revelation is written on a heavenly template which represents his word. ${ }^{69}$ This original template known as the "Mother of the book"70 has been made known to humankind at various times, in the Torah through Moses, ${ }^{71}$ in the Psalms through David, ${ }^{72}$ and in the Gospels through Jesus. ${ }^{73}$ The message of the Qur'an is said to confirm these earlier scriptures, but its authority is greater than theirs. ${ }^{74}$ The Qur'an issues a divine declaration: "What we have revealed to you from the Book is the truth, confirming what was before it." ${ }^{75}$ However, according to the Qur'an, Jews and Christians fail to recognize the Qur'an's continuity and authority. ${ }^{76}$ Thus the Qur'an rejects their claims of possessing full religious truth by asserting its own continuity with Abrahamic monotheism and insisting that Jews and Christians conceal testimonies concerning this fact:

The Jews say: "the Christians promote nothing" and Christians say: "the Jews promote nothing," while they both recite scripture. Those who do not know speak likewise. God will judge between them on the Day of resurrection about that which they differ. ${ }^{77}$

The Qur'an also opposes the biblical assertion that Abraham belongs only to the Jewish and Christian communities by affirming that Abraham was a monotheist just like Muslims are; therefore, Jews and Christians have no special status in God's view:

The Jews and Christians have said, "We are God's children and His beloved ones." Say: "Why then does He punish you for your sins? Rather, you are human beings whom He has created. He forgives whom He wills and punishes who He wills. God has dominion over the heavens and the earth and what is between them, and to Him is the return."78

The debate continued by equating religious truth is equated with political success. The Qur'an declares Islam's destiny to military superiority and political

\footnotetext{
68 Sūrah 2:140.

69 Sūrah 85:22.

70 Sürah 3:7: 13:39, $43: 4$.

71 Sūrah 3:39; 6:154.

72 Sūrah 4:163; 17:55; 21:105.

73 Sūrah 5:46.

74 Sūrah 5:48.

75 Sūrah 35:31; Also Q 2:4, 41, 91, 97; 3:3; 4:47; 6:92; 5:46-48, $10: 94$.

76 Sūrah 2:88, 91, 170. These verses contain dialogues with Jews on true religion.

77 Sūrah 2:113.

78 Sūrah 5:18.
} 
success of because it follows the true religion: "It is He who has sent his apostle with guidance and the religion of truth, over all religion, however hateful the associators find it."79 From a Muslim perspective, God's faithfulness to his prophets and his people means that He gives them the power to overcome their enemies. ${ }^{80}$ al-Razi, in his commentary on Sürah 9:33, considers the ascendancy of Islam over other religions to be an indisputable proof of Mohammad's prophethood; God demonstrated that Mohammad was his prophet through political supremacy. ${ }^{81}$ al-Razi argues that there are three means by which this superiority can be achieved: first, by arguing and demonstration; second, by numerical growth and prosperity, and third, by victory and conquest. Ibn Taymiyya argues that the political ascendance of the Muslim community demonstrates that Mohammad is truly God's prophet. God granted victory to the prophets who came before Mohammad and punished their enemies and did the same for Mohammad and his community to an even greater degree. ${ }^{82}$ The success that God gives to the Muslim community is seen to be both religious and political, for "he made it conqueror with proof and a clear argument, and He had made it conqueror by power and spear."83

In regard to Christianity, Ibn Taymiyya recognizes that Christianity achieved some political success, but because of and through that success, Christian doctrine was corrupted:

To Christians one can say that they were continually conquered, overcome, and scattered throughout the earth until Constantine was victorious and established the true religion of Christianity in sword, killing those Jews and pagans who opposed him. However, the religion he made victorious was changed and corrupted and not the religion of Christ. ${ }^{84}$

Ibn Taymiyyah asserts that with the coming of Mohammad, God's Kingdom on earth was established to a degree never achieved before:

When God sent Mohammad, the absolute oneness of God and His service alone with no rivals resulted in a conquest as no people had never known it, nor had any prophets ever accomplished such... Most of the people of the earth are with Mohammad... [He and his people] brought about the conquest by the religion of the Lord, from the eastern part of the world to the west, by word and deed. ${ }^{85}$

79 Sūrah 6:19, repeated twice in Sūrah 9:33 and 48:28.

80 Sūrah 3:12; 24:55; 40:51; 37:171-173.

81 al-Razī 1938, 32-33.

82 Michael 1984, 177; cf. Roberts 2011, 210-235.

83 Michael 1984, 163.

84 Ibid. 362.

85 Ibid. 362-373. 
Gerasimus presents the points of the objection in a structure similar to that used by al-Razi and Ibn Taymiyya. In response to the statement that "pagan temples are replaced by the temple of saints," the objector argues that what is actually seen is the opposite, "the temples are ruined and humbled," and Christians are under the protection of their Muslim enemies (vv. 11-16). Objection 1 concludes with: "your religion is not the religion of truth; otherwise, (as we mentioned before) the Hanif's religion would have been true in the past, and the Muslim religion would now be the religion of truth" (v. 17).

\subsubsection{Response to the Objection}

Gerasimus's response to the objection that Christianity is not the true religion can be divided into three sections. In the first he examines the spread of Christianity; in the second, the differences between the pagan message and the Christian one, and the third, reasons for Muslim ascendancy over Christianity.

\section{The spread of Christianity}

To complete the answer to the first section of the objection, it is necessary to refer to Part 3 of the Apology where Gerasimus examines, in detail, the spread of Christianity and responds to the criticism that Christianity is not the most widespread religion. As he begins his response to this objection, he states: "We already answered this before, and there is no need to say more than we already said" (v. 18). In the third part he examines how the three signs of the true disciple and true religion are evident in the Christian disciple. He also responds to the objection made against the spread of the Christian faith. Although an edited translation of Part 3 of the Apology of Gerasimus is not included in this book, it is helpful to quote the section in Part 3 where Gerasimus responds to the objection made against the spread of Christianity, with English translation:

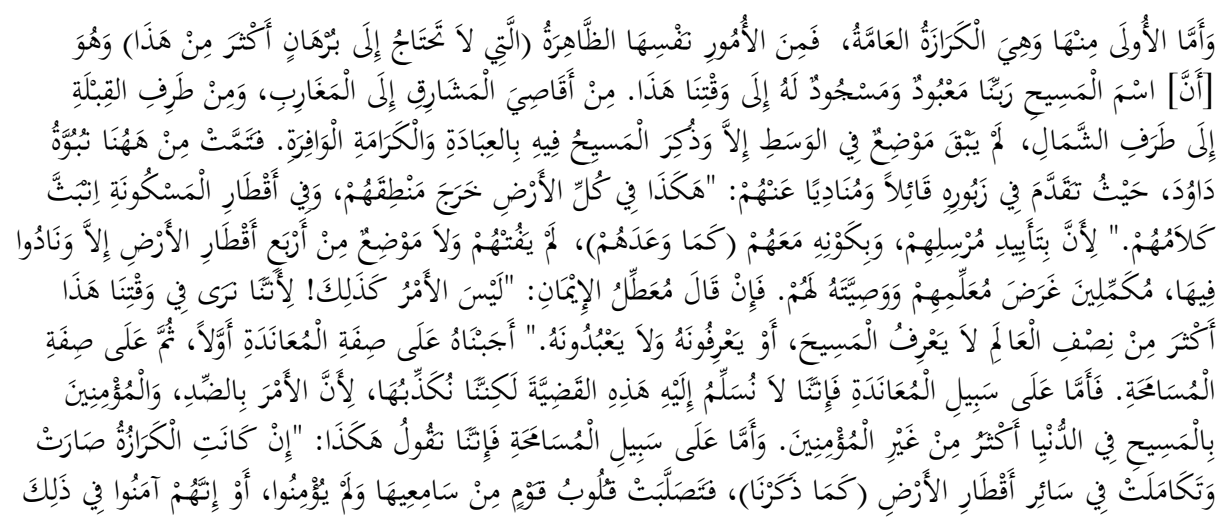




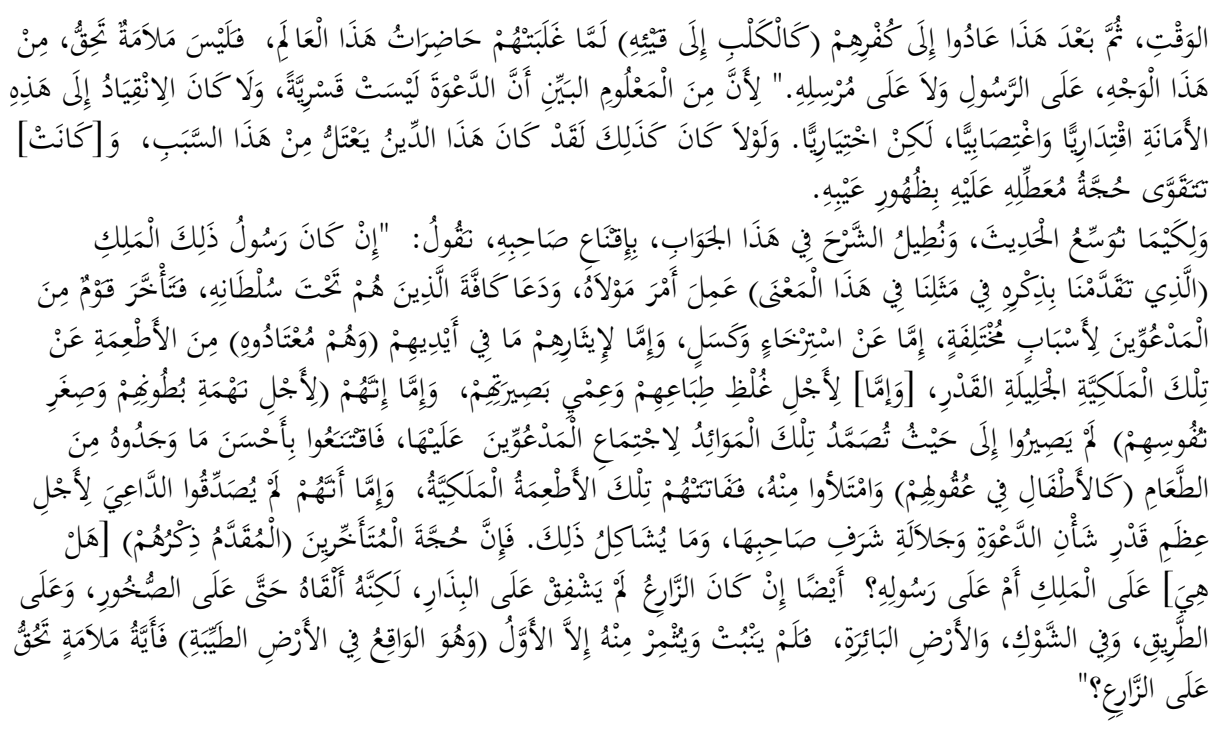

Regarding the First Objection one which is general preaching, it is one of the obvious matters that has no need for further proof, [to say] that up to our current time, the name of Christ our Lord is still worshiped and [he is still] bowed down to. From the farthest [corner] of the east to the farthest [corner] of the west, from the end of the Qiblah ${ }^{86}$ to the farthest extent of the north, there is no place where Christ's name is not mentioned in worship and [given] abundant honor. This has fulfilled the prophecy of David, who said in his Psalm ${ }^{87}$ about [the disciples] "For [in this way] their logic ${ }^{88}$ has gone out through all the earth and their speech has spread to the ends of the world." 89 By the strength of the One who sent them, and by being with them as He promised, nowhere in the four corners of the earth has not been overtaken by their call. [In this way] they fulfilled the purpose and command of their Master.

But the objector of the faith claims, "The matter is not like this! For we see in our current time that more than half of the world does not know Christ, or they know Him but are not worshiping Him."

We respond to him at first with in a stubborn way, then with a forgiving manner Determined, we do not surrender this matter to him, but we disprove it, because it is untrue, [thus we say:] There are more believers in Christ in the world than nonbelievers. And in a forgiving manner we say, if preaching is done and carried out in

86 Qiblah: The south, as defined in terms of the direction of the $k a$ 'bah - the direction Muslims face during their prayer.

87 Here, for "psalm," Gerasimus uses the Quranic term Zabbūr, instead of the biblical term Mazmūr.

88 He uses the Arabic word Manțiq which means "logic."

89 Psalm 19:4. 
all the countries of the earth (as we mentioned) but the hearts of some listeners are hardened and they do not believe, or, they believed at one time, then went back to their infidelity (as the dog to its vomit) when the pleasure of this world overcame them, in this respect, no blame is due to the disciple, or to the one who sent him, for it is well known and proven that the preaching [to call people to Christian faith] is not coercive, and submission to this faith is not by power, or extortion, but by choice. If it were not so, this religion would have become, for such reason, unhealthy, and the objection of its obstructers would have been strengthened in revealing the defect [of the faith].

And, because we do not want to talk too much and prolong the interpretation in this answer [to try to convince the obstructer of the faith] we say: When the disciple of that king (already mentioned in our parable) executed his master's command, he invited all who were under the king's authority. However, some of those invited delayed for different reasons, either out of laziness or laxity, or because they preferred the food they had in their hands (which they were used to taking) more than the royal offering, which was majestic and honorable, or because of stubbornness of their nature and blindness of their sight, or, because of the craving of their bellies and the lowliness of their souls, and they did not attend the banquets that were prepared for the invited. They remained, instead, convinced that the food [in their hands] was best, and like mindless children, were satisfied with it, thus missing the royal food; or, they did not believe the one who invited them because they were impressed by the importance of the invitation and the majesty and honor of its owner; or similar [excuses]. Therefore, the excuses of the delayers (previously mentioned) are due to whom, the king or his disciple? [Similarly,] if the sower had no compassion on the seed, but threw it also on the rocks, on the road, in the thorns, and on uncultivated land, and no seed grew but the first one (that is, the one that fell on the good soil), ${ }^{90}$ what blame is due to the sower? (Part 3).

He then discusses the reason miracles are not performed in his time as they were in the beginning of Christianity.

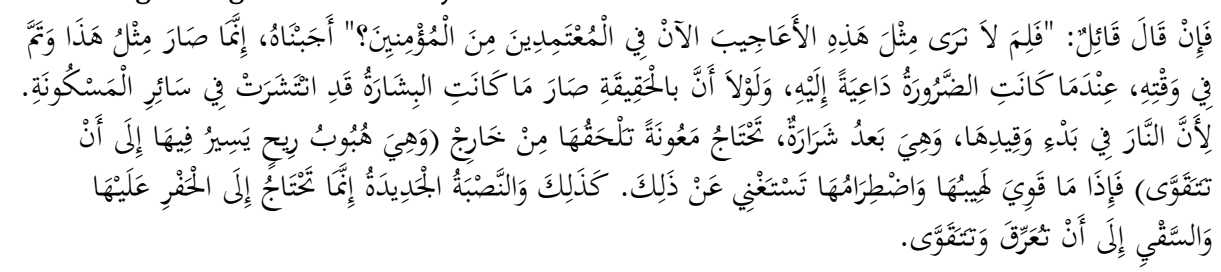

If the speaker asks, “Why don’t we see miracles performed by baptized believers like those [of early Christianity] in our time?” We answer him that this happened and was completed then because it was necessary then. If in reality this would not have happened, the Good News would not have spread throughout the world. When fire begins to ignite, and while it is still a spark, it

90 Matthew 13:1-9. 
needs help from outside, that is, a wind blowing on it to strengthen it. When it blazes and the flames are strengthened, there is no need for [wind] anymore. Also a new plant needs digging and watering until it is rooted and strengthened (Part 3).

What we see here is a response loaded with biblical imageries, verses, and parables. Most probably the response was part of a sermon intended to edify Christians in their faith. It is also reminiscent of many liturgical chants in the Eastern Orthodox traditions. Gerasimus starts by quoting from Psalm 113:3-4: "From the rising of the sun to the place where it sets the name of the Lord is to be praised. The Lord is exalted over all the nations, his glory above the heavens," ${ }^{11}$ and from Malachi 1 "My name will be great among the nations, from the rising to the setting of the sun. In every place incense and pure offering will be brought to my name, because my name will be great among the nations." ${ }^{92}$ Gerasimus makes some changes in words, for example, instead of "south" he writes "qiblah" which is the direction for Muslim prayer. He then declares that this statement is fulfilling the prophecy of Psalm 19:4 and the promise of Jesus to be with his disciples in John 14-16. He then points out that the weakness is not in the Christian message, or faith; it is in the people who believed in the message, but when the pleasures of this world overcame them, they returned to their old lifestyle "like a dog to his vomit." This analogy is taken from Proverbs 26:11 and 2 Peter 2:22. He then presents another biblical parable, that of the wedding banquet in Matthew 22:1-14, and continues to build his response by quoting and interpreting other biblical passages like 1 Corinthians 3:1-3, 2 Corinthians 3:14, and Ephesians 4:14-26. He concludes with the parable of the sower in Mark 4:14 and Matthew 13:1-9.

In his answer to the statement that "no miracle is being manifested in your midst," Gerasimus believed that miracles were needed only for the time of Jesus and the apostles as witnesses to His person, to give proper credentials to Christ and to demonstrate that the gospel message was from God. With the end of the New Testament era, however, the need for miracles ceased. Gerasimus believed that the written word speaks for itself and is attended by the convincing power of the Spirit. ${ }^{93}$

\subsection{The Differences Between Pagan and Christian Messages}

The second point that Gerasimus responds to is the differences between pagan and Christian messages. The term he uses for pagan is hanif. It occurs twelve times in the

91 This Psalm is chanted in the morning common prayer service of the Antiochian Syrian Church. See Evening and Morning Prayer According to the Rite of the Syrian Orthodox Church of Antioch, 2002. 92 Malachi 1:11.

93 Cf. Walvoord 1991, 173-174. 
Qur'an, with seven of those associated with Abraham as the model of true faith. ${ }^{94}$ This term has a double meaning within Syriac; it can mean both pagan and a monotheist believer. Christian Arabs adapted the Syriac term first to indicate "pagan," "Gentile" or "Greek." "95 We can clearly see that Gerasimus's use of hanpe means "pagans" because he uses the same apologetic argument as the Church Fathers against pagans. His response is that Christians have one unified message while pagans have many and diverse opinions vv. 21-23). Cyril of Alexandria, for example, in his defense against Julian the Apostate, defended the Christian message against his pagan counterpart's critics in a similar way:

Readers, now you have heard and understood what drivel all this is! Opposing their opinions one to another, vociferating this or that, mixed up anyhow, without nuances, self-reflection, just at their pleasure; how can this avoid the impression that they are just guessing at the truth rather than knowing it? Indeed, some prefer just one universe, others a plurality; some of them believe that this universe is subject to creation, but others are opposed totally to this and opine on the contrary that the universe is imperishable and was not created; some say it is governed by a divine providence, others do without providence and allot the harmonious movements of the elements to automatic mechanisms and accidents; some say that the universe has a soul, others deny that it has a soul or a spirit. In short you could imagine that their theories on each detail are just tossed together, like mixed drinks!...So which one do we give our approval to, when we seek the truth, when we seek to start along on the irreproachable way from which every error is banished? Which of the thinkers quoted can we declare innocent of the wrong of telling a lie? Which do we reward as not having stumbled in some detail? Or rather how can we grant a right to teach others, to those who have traveled so far from the truth that they disagree not only with each other but even with themselves? ${ }^{96}$

Gerasimus then argues that Christians are not like pagans. Despite the fact that Christians do not agree on the mystery of the Divine Economy, they all agree on the foundation of religion. They are the children of one baptism, follow the preaching of one gospel, share one hope, and are walking in one right royal way (vv. 24-26).

Gerasimus wants to portray Christianity positively by stressing Christian unity, which was one of the major and oldest themes in literary dialogues addressing Christian-Muslim relations. Christian writers emphasized that Christians follow one Gospel, one Baptism and one Law. ${ }^{97}$ The message of Christian unity served two

94 Abraham is mentioned as the model hanif in the Qur'an, in surahs 2: 135, 3: 67, 3:95; 4: 125, 6: 120, 123.

95 Cf. Griffith 1995, 8-14; Griffith 1983, 118-121.

96 Russel 2000, 192.

97 An example of early dialogue on Christian unity is the dialogue between John of Sedra and the Muslim Emir. The first question that the Emir asked John is: "If Christian follows the same Gospel?" John's answer: "it is one and the same Gospel to the Greek and the Romans and the Syrians and the Egyptians and the Ethiopians and the Indians and the Armaneans and the Persians and the rest of all people and languages.” For more on this see Penn 2003; Penn 2008; and Saadi 1998. 
purposes. Theologically, it served as a proclamation of the universal Gospel and as a defense against the Muslim conquest and political pressure related to Christian division. Muslims accuse Christians of being divided and having no unified message, therefore they cannot govern themselves. Christian Arabs expressed their ability to govern themselves according to the criteria accepted by all Christians. ${ }^{98}$

Gerasimus then concludes by stating that Christ died for all humanity and whoever believes in Him shall be saved. He quotes Philippians 2:10, "every knee should bow, of those in heaven, and of those on earth and of those under the earth" (vv. 27-33).

The third point is reasons for Muslims' ascendance over Christians. Eastern Christians saw the coming of Islam as God's judgment on the Christians, the people who had erred. Various Eastern Christian writers expressed this view though interpreted it differently. The Monophysites and the Nestorians, who rejected the Council of Chalcedon (A.D. 451), and who were persecuted because of this, saw the coming of Islam as a judgment of God against their Melkite enemies who accepted the Council of Chalcedon. This is illustrated by Severus of Asmounein, the Coptic editor of the Egyptian History of the Patriarchs He wrote, "The Lord abandoned the army of the Romans as a punishment for their corrupt faith, and because of the anathemas uttered against them by the ancient fathers, on account of the Council of Chalcedon."99 The Melkites, on the other hand, saw the coming of Islam as a judgment of God against human transgressions. ${ }^{100}$ Between the years 634 and 640 A.D. the Meklie, Maximus the Confessor, wrote a letter to Peter the Illustrious. In it he explained that Arabs succeeded in their conquest because of Christian sin:

For we have not conducted ourselves in a manner worthy of the Gospel of Christ....We have all acted like wild beasts towards one another, ignorant of the grace of God's love for humans, and the mystery of the suffering of the God who became flesh for our sake. ${ }^{101}$

Another source of the Melkite view of Islam is the writing of Sophronius, Patriarch of Jerusalem, who, in his sermons, preached that Christians were experiencing the tribulation of Islam because of their own wickedness, and like Maximus, he thought that repentance would turn the Muslim advances. ${ }^{102}$ He used biblical analogy by recalling the Babylonian ruler Nebuchadnezzar who destroyed Jerusalem, and whose action was interpreted by some of the Old Testament prophets such as Jeremiah, as evidence of God's judgment on a decadent Israelite community. Gerasimus builds his defense upon such theological interpretations of Islam. As a Melkite, he adapted his

98 Cf. Bertaina 2011, 89.

99 Goddard 2000, 37.

100 Cf. Eichner 2011, 109-173.

101 Migne 1857-1886, 540.

102 Ibid. 540. 
forebearers' interpretations; he reads the coming of Islam as a judgment from God because of Christian sin.

As to the reason for the ascendance of the nation of Mohammad (I mean the Muslims) over the children of the Holy Baptism, and their oppression of them, it is because [the Christians] strayed from keeping the Divine and life-giving commandments (that have in them what sustains the health of their souls) and inclined toward sin (that sickens their souls and destroys them). (v. 34)

He then moves to biblical imagery presenting the sword of Islam as a sort of discipline for Christians.

Moreover, there are many kinds of punishment. (I mean the punishments of the Lord are many and different, such as locusts, lice, snakes, rats, savage beasts, and others similar to this.) The sword of Islam, and its authority over the Children of Baptism, is but one form of these punishments, similar to the chastisement of [the Lord] in the past when the children of Israel deviated from the commandments of His laws. (vv.39-41)

He continues to build his treatise on biblical imageries from the prophets of the Old Testament stating that God has no desire for our worship when we anger Him; our supplications are vile if we deviate from His commandments and anger Him with our deeds (vv. 42-43). ${ }^{103}$ Gerasimus concludes the response to the objection by stating that his purpose in this treatise is to prove the honor of the Christian religion and its truthfulness in and of itself. We don't judge any religion based on its follower's conduct but based on its teachings (v. 48). He then adds that a Christian's hope is not in this world but in the world to come (vv. 50-54).

\subsection{Second Objection: Questions about the Trinity and the Divinity of Christ}

\subsubsection{Summary of the Objection}

- How can Christians attribute a son to God, and then declare that God is three (Father, Son, and Holy Spirit). In effect, it appears that Christians worship three gods (vv. 55-56)?

- In addition to that audacity, Christians actually describe Jesus with human characteristics, and say that he was crucified, that he died and that he was buried; yet they worship him as God (vv. 57-58).

103 This statement resonates with many prophetic warnings against the people of Israel in the Old Testament, such as in Amos 5:20-23 and Isaiah 1:1-20. 


\subsubsection{Context of the Objection}

This objection is at the heart of Muslims' attacks against the Christian doctrine of the Trinity, Incarnation and Jesus's passion and death. The Qur'an clearly rejects this doctrine and condemns those who believe in such ideas:

The Jews call 'Uzair a son of God and the Christians say Christ is the son of God. That is a saying from their mouths. (In this) they but imitate what the unbelievers of old used to say. God's curse be on them, how they are deluded away from the truth! ${ }^{104}$

That they said (in boast): "We killed Christ Jesus, the son of Mary, the apostle of God.” But they killed him not, nor crucified him, but so it was made to appear to them, and those who differ therein are full of doubts, with no (certain) knowledge, but only conjecture to follow for of a surety they killed him not. ${ }^{105}$

O People of the book! Commit no excesses in your religion, nor say of God aught but the truth. Christ Jesus the son of Mary was no more than an apostle of God, and His Word, which He bestowed on Mary, and a Spirit proceeding from Him, so believe in God and His apostles; Say not "Trinity," desist, it will be better for you, for God is One God, glory be to Him, far Exalted is He above having a Son. To Him belong all things in the heavens and on earth. And enough is God as a Disposer of affairs. ${ }^{106}$

Underlying these words in a belief in the transcendence of God who is absolutely different from any creature and the fear of associating, or assimilating, any creatures with God. The Qur'an frequently asserts the transcendence of God, stating that "nothing is like Him."107 The commentators of the Qur'an and Muslim theologians based their arguments on these verses and attacked the belief that Jesus is the Son of God and the Trinity. ${ }^{108}$

\subsubsection{Response to the Objection}

In the response to this objection, Gerasimus considers three aspects of Christian dogma: first, the divine birth of Christ and the Holy Trinity; second, the passion of Christ and the reason Christians honor it; and third, the ground for God's condescendence.

104 Sūrah 9:30.

105 Sūrah 4:157.

106 Sūrah 4:171.

107 Sūrah 42:11.

108 For more detail about Muslim polemics against Christianity see, Thomas 2006, and Thomas 2002, 9-20, 37-48. 


\subsection{Divine Birth of Christ and the Holy Trinity}

Gerasimus responds to two objections made against the Christian doctrines of the divine birth of Christ-God as one substance-and the Trinity. Muslims object to the first doctrine because for Muslims to say God is a substance (ğawhar) is to make God a visible body that occupies, and is affected by space and time. They object to the Trinity because they understand this doctrine to mean that "God is three gods" which associates God with other gods. ${ }^{109}$ This is considered unforgivable blasphemy. To say that "the three persons of the Trinity are personal attributes of God (hawāṣs mušahhașah)” complicates the matter more because according to Muslims God has more than three attributes. ${ }^{110}$

As he did in response to the first Objection, Gerasimus reminds his readers that he has already examined this subject in Part 1 of the Apology. He then affirms that the statement "God is three persons" does not mean three gods, but that "God Almighty, His Word, and His Spirit are Father, Son, and Holy Spirit” (vv. 59-60). This is similar to the Qur'anic description of Jesus as a spirit and a word from God: "The son of Mary, and apostle of God, and His Word, which he bestowed on Mary, and a Spirit proceeding from Him." 111 Gerasimus builds his case on foundations acceptable to Muslims, taking into account the way Muslims see Christ. While they refuse to speak of him as God's son, they call Christ God's word and spirit. If Christ is word and spirit that comes from God then surely he shares attributes of God in such a way that makes him divine as well as human.

Gerasimus then states that our minds cannot contain the idea of the divine birth of Christ and the doctrine of Trinity, thus it must "be honored by silence" (v. 61). Therefore, when we explain such an idea we resort to human language and analogies.

"How then could the mind imagine it? Or how do our tongues handle it? There is no ability to understand it, or to talk about its form, other than to say: "He was a Father, and a Son was begotten from Him," either like a ray from the sun, or like a word from the mind, or another similar analogy (vv. 63-64).

Gerasimus borrows extensively from the theological discourses of the Cappadocian Fathers and John of Damascus ${ }^{112}$ on the Son and His divine birth. ${ }^{113}$ He also makes use of the "without knowing how" principle of God's actions that is a familiar part

109 The term used by Muslims here is, širk. It means to associate God with other gods.

110 Cf. al-Hुūrī Būls 2007b, 9-58.

111 Sūrah 4:171.

112 Cf. Andrew 2002, 18-19; and Baher 2004.

113 John 2004, 334. 
of Muslim theology, and was used by Arab Christian theologians such as 'Ammār al-Bașrī. ${ }^{114}$

Gerasimus then affirms that Christians do not worship three gods. When Christians speak about the Trinity they do not talk about three separate persons, but about God with one substance and three personal attributes (hַawāṣs mušahnhașah)

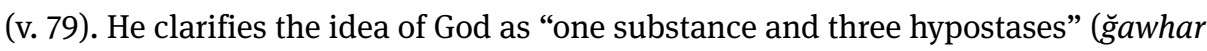
wāhid wa talātat aqānim), stating that Christians do not intend to present three separate persons as in the separation of humans.

For if we were all gathered under one mind, we would share one substance, and one form would prevail over all of us, but we are different in many things (I mean, time, place, determined will, and other characteristics that are parting and dividing us are different from person to person. They can be found in one individual, but can never be shared with another one). It is to the point that these differences are not only present among us, but every person, from time to time, also experiences transformation, change, and fluctuation, from one state of mind to another. (vv. 76-78)

He then compares this to God and the persons of the Holy Trinity:

\begin{abstract}
Regarding the Creator of all, although He consists of three persons, the difference is only in the "personified forms and attributes," [that is to say], each person [of the Trinity] has special attributes that distinguish and differentiate Him from the other persons; however, the agreement between [the persons of the Trinity] are many because He is one God with one substance, one nature, one honor, and one eternity. ([These characteristics] are not uniform among us humans. Every one of us has a different nature.) The totality of every one of the three is in the totality of the other two, yet He is fully God; and the three are one God, and every one of the three is Himself the other two, except in the personal attributes (mentioned above). Through [these attributes] only, not by any other, [the human] mind distinguishes the one from the other (vv. 79-82).
\end{abstract}

In this section Gerasimus uses the same format John of Damascus uses in his book An Exact Exposition of the Orthodox Faith. ${ }^{115}$ Following the steps of the Arab theologian, Gerasimus defends the belief that fatherhood and sonship in the Godhead are not comparable with their human equivalents and are of such a form that they do not violate God's unity and transcendence. He uses the two arguments Abū Qurrah used in reply to those who deny the incarnation: ${ }^{116}$ First, if God were unable to beget a son, then he would be weak, and if he has begotten a son, he himself is no earlier in time than his Son. Unlike human beings, God's willingness to have a son is identical to his act of begetting. Second, God must have authority but not merely over something

114 'Ammār concedes in his response to the Muslim objection against the idea of the Incarnation that some things cannot be known for certain: "We do not know how the divine united with the human. This is analogous to creation. We do not know how God creates." Cf. Beamont 2003, 59; Beamont 2005, 79; and Griffith 1983.

115 Andrew 2002, 18-19.

116 Dick 1982, 224-228. 
as inferior as a created being, so God must be over an equal who is of the same nature as himself, hence a son.

Gerasimus also uses most of the synonyms used by Arab Christian theologians to explain one substance ( ğawhar wāhid) with expressions like "one kind” (naw wāhid) and "one form" (șürah wāhidah) that express the one substance of God. ${ }^{117}$ When he writes about the persons of the Trinity (aqānim) he calls them, "the personified forms and attributes" (al-aqānim al-mušahhhașat al-ūğūh). This usage is similar to what Arab Christian theologians called "personal attributes" (hawās ḍātyyah). It explains that the three persons of the Trinity are personified attributes, or manifestations, of one substance. ${ }^{118}$ Arab theologians began with the notion of the divine attribute (șifa), which was well known in the Muslim tradition, and also represents the Muslim manner of reconciling the inevitable multiplicity of human language about God with the uniqueness of the divine essence. ${ }^{119}$ The theologians then add their own specifications to indicate that the persons are of a different order from the attributes. Ibn al-Tayyib speaks of attributes "specific to the divine essence" (tahușṣ al-dat) while other writers connect the relationship of God to creatures. ${ }^{120}$ Paul of Antioch speaks of "substantial" (ğawhariyya) attributes equivalent to names which the One God gives Himself. ${ }^{121}$

Gerasimus uses the Syriac word qnūm to describe the persons of the Trinity, not the Arabic word uqnūm. Many Arab Christian theologians considered the Syriac meaning a more accurate one to express the oneness of God. ${ }^{122}$ al-Bașrī explains it in this way: "al-qnūm is a Syriac word that means the particular, complete substance that is selfsufficient, and does not need any other body." ${ }^{123}$ Gerasimus ends his discussion of the Trinity with the classical illustrations used by Abū Rā'ițah and Theodore Abū Qurrah: three lamps lighted in one home and three persons singing one Psalm (vv. 83-85).

\subsection{Passion of Christ and the Reason Christians Honor It}

Gerasimus's answer to this objection is a combination of biblical and patristic liturgical teachings. Similar to many eastern liturgical hymns that are chanted in the services on Good Friday, ${ }^{124}$ he first declares,

\footnotetext{
117 al-Hुūrī Būls 2007b, 11-45.

118 Ibid. 97-104.

119 Cf. Caspar 2007, 77-78.

120 Troupeau 1971, 71-89.

121 al-Hुūrī Būls 2007a, 19-21.

122 Ibid. 61-62.

123 Al-Ḥāīk Mîŝāl 1977, 162.

124 "The Order of Adoration and Exaltation of the Holy Cross and the Redeeming Burial Conducted on Good Friday.” Barsom 1984, 201-251.
} 
In regard to the passion of our Lord and Savior, we not only do not despise it, but we affirm it about Him and confess that through it our salvation was wrought. We, therefore, proclaim it, honor it, and declare it, not only by words, but also by deeds. We display it in the Holy Church, on the roads, and in most places (I mean His crucifixion and passion) that we may remember it and be proud of it. Our purpose in this is to announce the favor of our Lord upon us, His level of grace regarding our salvation (vv.86-89).

He then compares the passion of Christ to a servant who fell into the harshness of captivity. His master redeemed him by enduring the hardship that the servant had to endure. He put on the servant's filthy garment and the chains of captivity, and suffered on his behalf. The servant, after his liberation, clothed himself with the filthy garments and the chains of captivity and walked around proclaiming the favor and goodness of his master (vv. 90-94). Gerasimus then states that the passion of Christ is foolishness for the world but for us it is the power of God (vv. 96-103; referencing 1 Corinthians 1:18-21, 25, 1 Corinthians 2:1-6, and Galatians 4:16). He then turns to the question: Why do the Bible and the church's books use humble terms to describe Christ? His answer: God was depicted in the Bible as a created human because Christ is fully God and fully human. He is fully divine, equal to His Father and fully human, equal to His mother and humankind. Therefore, sometimes the Bible talks about Jesus as human, and other times as God (vv. 104-107).

Two important points merit our attention in this interpretation. First, the passion of Christ shows how much God cares for humanity; human beings ought to proclaim such love and favor. "Our purpose in this is to announce the favor of our Lord upon us, His level of Grace regarding our salvation,” (v. 89) writes Gerasimus. Second, Christ has two natures, divine and human. The two natures of Christ have separate points of origin, but an ultimate unity. The divine is eternal, the human is bound by time, but after the union of eternal and temporal there is a unity of being. His suffering and death did not affect Jesus's divinity; only his human body suffered.

\subsection{Reasons why God Condescended}

Gerasimus begins his discussion of God's condescension by showing that His act of creation demonstrates his grace and generosity, and his appearance as a human being was his supreme act of communication and the culmination of his generosity toward creation. The appearance of God in flesh is the best form of revelation, since it was not enough for God to send a prophet to declare his message. It was God's ultimate plan to reveal himself to humanity in Jesus, so that no one could have any doubt about the character of God. ${ }^{125}$

125 Beamont 2005, 70-71; Thomas 2002, 54. For more detailed analysis of how Arab Christian Theologians presented the concept of the Incarnation see the two volumes of al-Hūūī Būls 2004. 
For this and similar reasons, it was necessary that the Lord of all (according to the law of the economy of our salvation, and out of His favor and goodness) would condescend from His exalted glory to the point of being equal to us. [He did this] to communicate with the human body by a human body, and to teach us divine conduct through a human body taken from our physical nature (vv. 111-112).

This argument, as Beaumont $(2005,71)$ points out, is a direct challenge to Muslim notions of revelation which are bound by the transcendence of God, and thereby preclude revelation being given by human speech, safeguarding the character of God from contamination or limitation in his relationship with humanity.

Gerasimus adds two more reasons for the incarnation when he answers the fourth objection: to deceive Satan (vv. 196-207) and to teach humans how to wrestle with Satan (vv. 208-213), both of which we have already discussed in Chapter 3. Gerasimus avoids talking about incarnation as a means of ransoming souls, or winning them from the devil. The act of incarnation was not in the first instance a matter of physicality, but rather it revealed God united with humankind through the saving economy. Gerasimus is aware of the context in which he is writing and the need to explain why God should appear in a bodily form and how. The emphasis is on the possibility of incarnation and the distinction between God and the created order. God's direct communication through a human is the inevitable culmination of his relationship with humankind; such relationship is more direct and superior than any other kind of communication.

To explain this point Gerasimus uses three illustrations: 1) It would be impossible for a pedestrian to reach a man sitting on a horse if the latter would not dismount his horse and walk with the pedestrian (v. 109). 2) Nobody can teach another to swim while he is in a boat. The instructor needs to take off his clothes and dive into the water in order to teach somebody to swim (v.110). 3) A deaf-mute cannot understand a speaker if the latter hides his speech and does not become equal to the deaf-mute by using his hands and fingers to communicate (v. 114).

Gerasimus concludes by saying: "the union of the Word of God with the human body and His suffering does not harm the Divine Nature” (v.115), referring back to two illustrations used in Part 1, the illustrations of the sun and a man (vv. 116-131).

\subsection{Third Objection: God Allowed Adam to Fall, and Did Not Repel Satan}

\subsubsection{Summary of the Objection}

The third objection takes the form of questions, asking

- Why would God create humanity knowing that it would fall?

- Why God would allow Adam to sin instead of stopping the work of Satan? 
- $\quad$ Since Adam did sin, why God did not save him before his sin increased? (vv. 132134).

\subsubsection{Context of the Objection}

This objection originated in the Muslim doctrine of free will and predestination. In the Qur'an (as in the Bible) the dogma of God's predetermination of fate is ambiguous. It says that God is the Omnipotent Creator. He creates all things ${ }^{126}$ in heaven and earth and all that is between them. ${ }^{127} \mathrm{He}$ is the Creator of humankind. ${ }^{128}$ God writes faith or unbelief on the hearts. He foreordains the human destiny from before birth. ${ }^{129}$ He sets the length of life and the day of death. ${ }^{130}$ Everything is written before being created. ${ }^{131}$ Good and evil fortunes come from God. ${ }^{132}$ Yet, the Qur'an affirms strongly that human beings are free and responsible for their actions. The verses most often quoted by theologians are: "Let whoever wishes believe, let whoever wishes be an unbeliever,"133 and "Whatever good happens to thee is from God; whatever evil happens to thee is from thy soul."”134

While the Qur'an's teaching does not confirm nor deny human responsibility, Muslim theology and tradition affirm the doctrine of predestination. In about 702 A.D. Orthodox Islam anathematized, as the worst heresy, the idea of free will or man's independence from God. The Qadarites ${ }^{135}$ and Mu'tazila, who upheld the doctrine of free will, were branded by traditionalists (muhadditūn) as dualists for setting man up as a co-creator with God by asserting that man initiated his own action and determined his own destiny. ${ }^{136}$ Several Hadith statements affirm predetermination. God is identified with dahr which means Destiny. A hadith qudsi ${ }^{137}$ affirms that God has declared "I am dahr." All is written by the heavenly pen qala in the eternal book before it takes place. All the actions of human beings are written by the angels when the embryo is still in the mother's womb: their sex, and the material and spiritual

\footnotetext{
126 Sūrah 6:101; 24:2: 39:62.

127 Sūrah 5:19-20.

128 Sūrah 37:96.

129 Sūrah 3:6.

130 Sūrah 3:154-158.

131 Sūrah 57:22.

132 Sūrah 9:51.

133 Sūrah 18:29; 73:19; 76:29.

134 Sūrah 49:79.

135 Qadarites, School of thought in early Islamic period. It was influenced by the Greco-Christian theologians. They insisted that man had power over his own deeds even though the fate of man has been preordained. Their doctrine and teaching was held to be heresy. Cf. Farah 2003, 207-208.

136 Morris 1964, 23-26.

137 hadith qudsī is a hadith which is attributed directly to God himself and not just to the prophets.
} 
provision for their whole life, the length and ending of their life, the good and evil actions they will carry out, and their eternal destiny to paradise or hell. ${ }^{138} \mathrm{Al}$-Bukhari quotes a tradition in which Adam demonstrates to Moses that his fall was preordained:

The Prophet said, "Adam and Moses argued with each other. Moses said to Adam. 'O Adam! You are our father who disappointed us and turned us out of Paradise.' Then Adam said to him, 'O Moses! Allah favored you with His talk (talked to you directly) and He wrote (the Torah) for you with His Own Hand. Do you blame me for action which Allah had written in my fate forty years before my creation?' So Adam confuted Moses," the Prophet added, repeating the statement three times. ${ }^{139}$

\subsubsection{Response to the Objection}

Gerasimus summarizes what Abū Qurrah wrote on free will. ${ }^{140}$ He gives three reasons for God giving humans the gift of free will.

First, when God created Adam in His likeness and image, his purpose was to appoint Adam ruler over creation. We have already examined the term "image and likeness of God" in Chapter 2. One of the characteristics of man's image is free will, through which Adam was enabled to choose to obey God or misuse the gift God bestowed on him and decide not to obey. Therefore, if God, who foreknew that Adam would fall, had not created him because of this reason, the choices given to Adam would have overcome the purpose and goodness of God (vv. 135-142). It is as if we say, "If God foreknew that iron would be used for killing, why then did He create it? The same could be said about wine for drunkenness, or about the member of procreation for adultery, or about the tongue for lying and cursing" (vv. 143-144).

Second, the reason God allowed Adam to fall is that if He forced Adam to obey Him, He would have robbed Adam of the gift of free will with which God had honored him. The gifts of God are never taken back (vv. 145-147). Gerasimus uses the expression al-qwwah al-istitā'yyah "the enabling power," which is used by the $\mathrm{Mu}$ 'tazila to indicate the physical ability that allowed human beings to act. The words used from the Mu'tazila are qudra hā ditha which means created capacity that gives human beings an enduring ability, and istita $\bar{a}$ ' $a$, to produce action and to choose freely between good and evil. ${ }^{141}$

Third, God allowed man to fall so that man might appreciate the grace and mercy of God. When God saves man through His Divine Economy, man will appreciate the

138 Caspar 2007, 155-156.

139 al-Buhārī, Sahih Volume 8, Book 77, N. 611, University of Southern California, Muslim Students Association, Compendium of Muslim Texts.

140 Lamoreaux 2005, 195-298; cf. Griffith 1987.

141 Caspar 2007, 159, 161. 
goodness of God and will recognize the harm of disobedience and the reward of obedience (vv. 148-152).

Gerasimus concludes his response with the parable of the good physician and his beloved student which has been discussed in Chapter 3.

\subsection{Fourth Objection: God Condescended and Shed His Blood On the Cross}

\subsubsection{Summary of the Objection}

- Since God, the Creator, is Almighty, He could speak one word to provide salvation for Adam and his descendents. In light of this, the abasement of suffering and death on a cross is incomprehensible (vv. 188-189).

- Furthermore, it is said that Christ bought humankind with His blood. It is unbelievable that God would purchase humankind with the blood of Christ, as it is understood that Satan is the seller, and that he would have been paid with the blood (vv. 190-192).

\subsubsection{Context of the Objection}

The first objection-why God did not complete the salvation of Adam in one word-has its foundation in the Muslim scriptures that reject the atonement and redemption and teach that God is almighty and omnipotent. Therefore, it would not be necessary for him to condescend and die on a cross. "To Him is due the primal origin of heaven and earth. When He decrees a matter, He says to it 'Be' and it is." 142 "Allah creates what He wills, and when He has decreed a plan, He but says to it 'Be' and it is."143

The second objection - He bought us by his blood - can be traced back to the teachings of Origen (185-254 A.D.) who believed that Jesus's human soul was given to Satan as a ransom to redeem humanity. But Satan could not hold Jesus's soul. ${ }^{144}$ Commenting on 1 Corinthians 6:20, "you were bought at a price," Origen says: "we must be bought from a person who enslaved us....Satan was the one who subdued us; we were standing in the same line with him because our sins drew us to him."145

142 Sūrah 2:116.

143 Sūrah 3:47.

144 Coptology 2007.

145 Ibid. 


\subsubsection{Response to the Objection}

Gerasimus's response can be divided into four points:

First, God's will was to save us through justice and fairness, not by power (vv. 193-195). Second, God's will was to meet like with like; this means that He would save us in the same way that Satan used to deceive Adam. As Satan clothed himself with the body of a snake to hide his nature and deceive the first man, likewise, God clothed Himself with a human body to hide His Truth from the deceiver. Deceived in this way, Satan then desired to wrestle with Him, and consequently, when Satan was defeated, God won the right to have us back (vv. 196-207, discussed in more detail already in Chapter 3.) Third, God wanted, through His union with human nature, to teach humanity how to wrestle with Satan (vv. 208-209). Fourth, through this saving economy, God fulfilled the work of his four effective attributes: mercy, might, justice, and wisdom (vv. 213-214). Gerasimus concludes his response with the parable of the Incognito King. This parable has been examined in Chapter 3 (vv. 214-261).

\subsection{Fifth Objection: Jesus Changed the Ordinances of the Old Testament Law}

\subsubsection{Summary of the Objection}

- It is unclear why God would change or abolish ordinances that he had established for the benefit of his people. Jesus was among those who were circumcised and ate the Passover meal. Yet, when He commanded His followers to be like Him, He did not expect them to keep these laws (vv. 263-265).

- If practicing the ordinance of the Law was necessary, even after Jesus completed the gift of Baptism and the Lordly Sacrifice, why then does he [Jesus] not command us to practice the ordinance of the Law? And if there are no benefits in practicing the Law, why didn't Jesus abolish it in its totality? Furthermore, why did [Jesus] discontinue many other Jewish practices such as the Sabbath, and not eating certain unclean food (vv. 266-267)?

\subsubsection{Context of the Objection}

The background of this objection can be traced to the Jewish teachings against Christians. Since the beginning of Christianity, Jews have criticized Christians for believing in the Old Testament and not practicing the ordinances of the Law. A good example of this kind of polemic between Jews and Christians is in the Apology of 
Justin the Martyr and his dialogue with the Jewish philosopher Trypho. ${ }^{146}$ We also find, among Christian Arab apologists, teachers like Abū Qurrah who defended the Christian faith by presenting treatises that explain the relation between the Law of Moses in the Old Testament and the Law of Christ in the New Testament. ${ }^{147}$ It is evident from this objection that these kinds of attacks were still flourishing in Gerasimus's time, and that he made use of the apologists before him.

It is also possible to deduce from this argument the following reasoning of Muslims: if Christ cancelled, or to use the Muslim expression abrogated, the practices and the commands of the Torah, similarly the Qur'an abrogated the Gospel. ${ }^{148}$ This is a common theme in inter-religious dialogue between Christians and Muslims. A famous example is found in the discussion between Timothy I and the Caliph al-Mahdī. The Caliph argues, "If Christ abolished the Law and its requirement, He is, therefore, its enemy and its adversary. We call enemies those who destroy and contradict one another."149 Timothy answers:

The light of the stars is abolished by the light of the sun, and the light of the latter is not for that enemy of the former; the functions of childhood are also abolished by those of manhood, and man is not for that enemy of himself; an earthly kingdom is also abolished by the heavenly kingdom, and the kingdom of God is not for that the enemy of men. In this very way Jesus abolished and destroyed the Law by the Gospel, while he is not for that the enemy and the adversary of the Law. ${ }^{150}$

\subsubsection{Response to the Objection}

Christian-Arab theologians rejected the idea of Christ abrogating the Law and firmly believed that Christ fulfilled the Law. Gerasimus based his response on this theological conviction.

First, Gerasimus explains that Christ did not abolish the Law, but, as He said in His Holy Gospel, He revealed its symbols and shadows. He completed the Law, confirmed it, and brought it to perfection (vv. 268-270). In defense of this point Gerasimus examines symbols and practices of the Law in the Old Testament that were fulfilled in the New Testament (vv. 274-288). He then presents four illustrations to explain his point: 1) The Law of Moses is like a tree that bears fruit seasonally, and the Law of Christ is like a tree that bears fruit all the time (vv. 289-290). 2) The Law of Moses is like a farmer who prepares his land and then cuts down the weeds on the surface leaving

146 David 2002, 22.

147 Lamoreaux 2005, 27-39; Nasry 2008a, 175-183.

148 This is Nasry's conclusion in 2008a, 127-129. See also Nasry 2008b, 180-181.

149 Mingana 1928, 28.

150 Ibid. 28-29. 
the roots. The Law of Christ is like the farmer that uproots the weeds (vv. 292-297). 3) The Law of Moses is like the moon and the Law of Christ is like the sun. When the sun rises, it does not eliminate the moon but hides it. Likewise, the Law of Christ did not eliminate the Law of Moses but covered it (vv. 304-306). 4) The Law of Moses is like mother's milk; it is beneficial and appropriate for the newborn. The Law of Christ is like food for the strong and mature who no longer need milk (v. 307).

Second, Gerasimus shows that the reason God ordained two laws is to gradually arrive at the knowledge of His full divinity (vv. 308-311). He uses four illustrations: 1) The four seasons of the year; we cannot jump from winter to summer without spring (v. 312). 2) Parents tolerate certain behavior in their children when they are young but will not tolerate the same conduct when the children grow up (v. 317). 3) Soldiers are trained for war with wooden swords but when they enter true battle, they use real iron swords (vv. 270-271). 4) The physician who gradually treats the symptoms of illness (vv. 318-319).

Following these illustrations, Gerasimus explains that when God realized humanity was falling spiritually, he knew this "illness" needed to be treated. Over time, God gave humanity different kinds of laws, but none could completely heal humanity's illness. God Himself had to carry the healing medicine and complete the healing.

The first medicine He gave and administered to [humanity] was the Natural Law, that is, discernment and vision (which can distinguish between good and evil and between what is appropriate and not appropriate for us). Then He gave it the Written Law. In it was explained the different kinds of medicine that the creator made for the human race. When none of these medicines was able to complete the recovery, and the illness had progressed to the point of being terminal, it was a necessary in due time for [human nature] to take the strongest medicine, which was appropriate for its grave illness. The making [of this medicine] required extreme measures because the disease was also quite extreme.

And when nobody except Himself could administer [this medicine], necessity demanded that He would be united with an earthly body that was taken from the nature of our bodies. [He did this] to be like us and to rightfully be able to teach us through [the human body] what He wanted to convey. Moreover, by [His] becoming equal to us we can rightfully be able to emulate what we see in Him. (vv. 335-340).

Third, Gerasimus then explains the purpose and the symbol of circumcision. God first commanded Abraham to be circumcised to separate him from other nations ( $\mathrm{v}$. 347). Then with Moses, God added the written Law (vv. 354-355.) Finally, when the time was complete, God Himself brought us the Divine Law that lifts us up to complete perfection (v. 356). Gerasimus then explains why circumcision was done on this particular member of the body.

349 We respond to him that the intention of God (glory be to Him) in forming this mark on this particular member has two reasons. 350 The first is that the image is marred when it loses any member; 351 therefore, this member was chosen to avoid disfiguring the human image. 352 It would not have been proper for the goodness of God to act like this, that is, to disfigure or deform 
the image of His own believers. 353 The other [reason] is in order not to have other marks similar to it because this mark (I mean maiming and cutting) is always practiced by thieves and those who would cause shame (vv. 349-353).

There are two points to be noted. First, the dignity of the human being: humans are created in the image and likeness of God. Second, the goodness of creation: God did not want to deform the human image and spoil the human body of believers. He concludes his point with the analogy of the owner of the village who offers help to his farmers, an analogy examined in Chapter 3.

Fourth, Gerasimus then responds to the question of why Jesus Christ practiced the Law of Moses. According to Gerasimus, the Lord Jesus was circumcised because the gift of baptism had not yet been given. He celebrated the Passover because the Lamb of God had not yet been sacrificed. He completed the duties of the Law to affirm that He is the One Who ordained it, and then He, Himself, presented the Law of Truth because He is the "Cornerstone" that contains both Testaments (vv. 387-393). ${ }^{151}$ Gerasimus, in his conclusion, defends the centrality of Jesus Christ throughout the Old and New Testaments. Everything that was practiced in the Old Testament was leading to Christ.

\subsection{Sixth Objection: Signs of True Disciple Not Demonstrated in Moses; God's Specific Calling to the Children of Israel Unfair}

\subsubsection{Summary of the Objection}

- Moses did not demonstrate the three signs of the true disciple which are preaching, performing of miracles, and speaking in the languages that are spoken all over the world. If these are the signs, then Moses should be called a false disciple (vv. 394-397).

- You say that God is fair and good to all, yet He sent a prophet and the Law to the children of Israel and excluded all other nations (vv. 398-404).

\subsubsection{Context of the Objection}

The first half of this objection is related the fifth objection, which concerns the relation between the Old and New Testaments. Why do Christians honor Moses and consider him a disciple if the signs of the true disciple are not all fulfilled in Moses? It is attested by the Bible that God's calling is universal, why then did God favor the Nation of Israel over the rest of nations? 


\subsubsection{Response to the Objection}

First, Moses himself recognized that he was not the ultimate and true disciple. He said, "The Lord your God will raise up for you a prophet like me from your midst, from your brethren. Him you shall hear"152 (vv. 405-407). Gerasimus briefly states that the coming of Christ is what gave importance to Moses. Only through the coming of Christ did the four corners of the earth recognize Moses (vv. 463-467).

Second, God did not send prophets only to the children of Israel, but their patriarchs (Abraham, Isaac, and Jacob) knew Him and sought Him before anybody else sought him (vv. 415-417). If God entrusted the children of Israel with His Law, His prophets, and His miracles, He bestowed upon the Greeks similar gifts of wisdom and knowledge, and also gave to the other nations what they needed (vv. 418-420).

Third, Gerasimus responds to the objection that the salvation of all nations was delayed. According to Gerasimus, God was certain of the calling and the salvation of all nations. He promised Abraham that he would become the father of countless nations. However, the calling and the salvation of the other nations was delayed for "many and diverse purposes" (vv. 421-423). Gerasimus lists the reasons that the salvation of all nations was delayed (423-453). We can summarize this list in one phrase: to complete the mystery of the Divine Economy (Cf. v. 424). In Eastern theology this meant, "God's plan to save humanity." The definition is inspired by Ephesians 1:10. The plan of salvation was to be implemented gradually; thus the Old Testament and its written Law and practices are considered a fundamental part of the Divine Economy. In this section, Gerasimus draws many connections between the symbols and practices of the Old Testament and their fulfillment in the New Testament. God intended to educate humans through the practices of the Law to bring them back to the point where God intended them to be, that is in fellowship with Him which was reached in the person of Jesus Christ. ${ }^{153}$ In Christ, reconciliation and agreement was completed between human nature and God, its Creator. Human nature was honored by its union with the Divine and ascended through Him above every lordship and authority (vv. 426-427). Gerasimus concludes his response with a second version of the well known analogy, the Incognito King (vv.469-531), which has been examined in Chapter 3.

Gerasimus bases his response on the Eastern patristic theology of God's universal call to salvation and the salvation of non-Christians. Some Fathers of the church elaborated a theology of the salvation of the non-Christian. Overcoming their original polemical attitude toward Greek philosophers, they moved towards respect for the faith of the pagan who is presumed to attain his salvation through it. According to Justin "the seeds of the word" are spread among all nations as a consequence of the Incarnation of Christ so that they can share, though imperfectly, the universal revelation of God.

152 Deutronomy 18:15, Acts 3:22.

153 Cf. Coptology 2008. 
Echoing this sentiment, Irenaeus writes about the "Cosmic Christ," meaning that God the Father revealed Himself to all nations, and even before the Incarnation, the Hidden Christ was present in the hearts of people until He was fully revealed when the word became flesh. The idea of "divine pedagogy" is present in Clement of Alexandria who sees the pagan philosophy as a path that leads to revelation. ${ }^{154}$

\subsection{Conclusion}

Gerasimus ends Part 5 with a liturgical benediction that is common in the supplications of the Eastern Churches: "We...offer glory, thanksgiving, honor, and power to the Father, Son and Holy Spirit, now, always, forever and ever. Amen.”

154 Cf. Fitzgerald and Casper 1992, 8-11; Sharp 2011, 52-72. 